Labinska H.B., Labinskyi A.Y.

\title{
Physical rehabilitation therapy and research of lipid spectrum in students with vertebro-basilar disease within
}

\author{
Stepan Gzhytskyi National university of veterinary medicine and biotechnologies, Lviv, Ukraine
}

lajboxnet@gmail.com

\author{
Лабінська Г.Б., Лабінський А.Й. \\ Фізична реабілітаційна терапія \\ та дослідження ліпідного спектру у студентів \\ з вертебро-базилярним захворюванням \\ Львівський Національний університет ветеринарної \\ медицини та біотехнологій імені С. Гжицького, \\ м. Львів, Україна
}

\author{
Лабинская Г.Б., Лабинский А.Й. \\ Физическая реабилитационная терапия \\ и исследование липидного спектра у студентов \\ с вертебробазилярными заболеваниями \\ Львовский национальный университет ветеринарной \\ медицины и биотехнологий имени С. Гжицкого, \\ г. Львов, Украина
}

\section{Introduction}

Vertebrobasilar insufficiency is more common in students, despite the fact that it was recently considered a disease of middle and elderly age [1,5]. According to the Tenth Revision of International Classification of Diseases, the vertebrobasilar insufficiency (VBI) symptom complex is considered to be a "vertebrobasilar arterial system syndrome" within the framework of "transient cerebral ischemic attacks and related syndromes" (G 45.0) [2,3].

Most frequently, VBI appears in adolescents 17 18 years, as during school classes at the university the cervical spine (SP), which holds the position of the head in space undergoes a long static load [1]. In today's conditions of rapid computerization development, the widespread use of gadgets causes forced posture of the head with the redistribution of postural muscle tone in adolescents, which leads to changes in the cervico-chest section of the spine and VBI [4]. The indicated syndrome is the result of metabolic changes in the cervical and thoracic spine [6,7].

At the forefront there are disorders in moving vertebral segments and their connective tissue apparatus, which leads to mechanical compression of the vertebral arteries [2,7]. Over time, the lack of blood circulation in the system of vertebrates and basilar arteries leads to disorders of lipid metabolism and brain activity [1,5]. Studying VBI is extremely topical, given the tendency to a rapid increase of this phenomenon, especially among adolescents, our future successors.

The purpose of the work was to study the effect of physical therapy on the course of vertebrobasilar syndrome in adolescents, in particular the tissues lipid homeostasis disorder, as one of the leading pathogenesis constituents in this vascular pathology [8]. The decision to use physical therapy was taken because medicinal treatment of this pathology does not give the desired effect, since the most common cause of VBI is spondylogenic, biomechanical disorders in vertebrate moving segments $[4,6,7]$.

\section{Materials and methods}

We examined 129 teenagers with spondylogenic vertebrobasilar insufficiency, students of Stepan Gzhytskyi National university of veterinary medicine and biotechnologies, girls (78) and boys (51) aged 16-18 years. In all the examined patients, periodic dizziness, headache, visual impairment were observed, and individual cases there was facial numbness, circumoral numbness, transient weakness in the limbs. At objective examination of patients, pain in paravertebral points and hypesthesia in segments $\mathrm{C} 5, \mathrm{C} 6, \mathrm{C} 7$, Th1, arterial pressure heterotonia, vertigo attacks were observed. The diagnosis was confirmed by radiography of spine. Verification of the diagnosis was carried out by methods of X-ray examination with functional tests, CT (computed tomography) and MRI (magnetic-nuclear resonance imaging) of the cervico-thoracic spine and ultrasonography (ultrasound diagnostics) of extracranial vessels.

At the same time, instability, lowering the of intervertebral discs height, listhesis of varying degrees, smoothed lordosis with osteoarthritis symptoms in various sections of the cervical and thoracic spine were revealed. At ultrasound scan (U/S), more or less severe signs of extravasal vertebral arteries compression were observed. After treatment, repeated studies were performed.

In the complex of physical therapy, methods of therapeutic exercises, treatment, massage, traction-manual therapy, and electrophysiotherapeutic procedures were used. Physiotherapy in the physical rehabilitation of patients with signs of osteoarthritis of the cervical spine was carried out in the form of amplipulse and diadynamic therapy for 1015 minutes per portion of the collar zone every other day for one and a half months. 
Manual and underwater massage of the cervicobrachial girdle were performed every other day in the amount of twenty sessions. Manual therapy was used in the form of the postisometric relaxation of all muscle groups of the cervicobrachial girdle with subsequent mobilization of those parts of the spine, where changes in the form of functional blocks in the intervertebral segments were detected by the manual and instrumental examination once a week for 2.5 months. Tractions of the cervical spine were performed if medically required under the subsequent X-ray control using a Gleason loop (15 sessions). Physical therapeutic exercises were assigned to all patients with the measurement of individual functional physical abilities using step-ergometric tests of functional classes 1 and 2 . The training was carried out within the framework of stage 1 for 2-3 months. The criterion for completing was the reduction of HR (heart rate) at the usual loads from peak to plateau formation per 20-35 cardiac contractions.

The tissues lipid spectrum study was carried out according to the method modified by Prof. P.V. Stapay (Institute of Animal Biology, NAAS) [9]. The following procedure is based on the classic Folch method and permits to obtain the largest amount of lipids from the tissues. For this purpose, the hair lock on the hind head was cut off in such a way that when re-cut, after 3 months, the newly grown hair would be obtained. The selected material was washed with shampoo in warm water, then in cold physiological saline and dried using filter paper.

For the extraction of lipids, a mixture of chloroform and methyl alcohol solvents was used in a volume ratio of $1: 2$. The material was first thoroughly cut very small with scissors, and then mulled in liquid nitrogen in a metallic mortar to a powdered state. The amount of the crushed hair weighing $0.5 \mathrm{~g}$ was filled with an extraction mixture and homogenized with a teflon piston. The homogenate was transferred into the test tube and left for extraction for 12 hours at the room temperature. Later, the homogenate was filtered through a fat-free paper filter. The precipitate was washed three times with small portions of the extraction mixture. Extracts were combined. To remove water-soluble, i.e. non-lipid admixture, $0.74 \mathrm{M} \mathrm{KCl}$ solution was added to the extract in the amount of $1 / 4$ of the lipid extract total volume. The content was shaken up and left for sedimentation until the complete liquids stratification. The upper water-methanol layer, lipids-free, is sucked off with a water-jet pump.

For the study, a lower chloroform layer containing lipids was used. It was filtered again through a fat-free paper filter into measuring tubes and brought the volume of $10 \mathrm{ml}$ with the extraction mixture. Usually the weight method is used to determine the total amount of lipids in biological objects. However, it is suitable mainly for objects with high lipids content, which is not always possible. Therefore, we suggest the self-developed simple and easily reproducible method stipulating the use of concentrated sulfuric acid.

The amount of $0.5 \mathrm{ml}$ lipid extract is introduced into pure and dry test tubes with pipettes. After preliminary evaporation of the extraction mixture under the exhaust hood,
$5 \mathrm{ml}$ of concentrated sulfuric acid is added to the test tubes and boiled for 15 minutes in a water bath. The content of the tubes is thoroughly mixed with a glass rod, cooled and measured using a blue light filter, using a $10 \mathrm{~mm}$ thick cuvet. Simultaneously, a blank sample with $5 \mathrm{ml}$ of sulfuric acid is studied. The total amount of lipids is calculated by means of the calibration curve.

Lipid fractions were determined by the thin-layer chromatography method. Glass plates sizing 20x6 cm, thoroughly washed in soda solution and chrome mix, were dried at room temperature. As an adsorbent, silica gel with particles of $120 \times 140$ mesh $(10-40 \mu \mathrm{m})$ was used. Silica gel was rubbed in a mortar with gypsum, which content was no more than $5 \%$. The suspension was immediately poured onto a dry glass plate and distributed on its surface with the layer thickness of $0.3 \mathrm{~mm}$. The dried plates were placed into the thermostat for 45 minutes at $110^{\circ} \mathrm{C}$ for activation.

The tested sample was applied to the starting line in the concentration of $2 \mathrm{mg}$ per $0.05 \mathrm{ml}$ of the solvent. The test plate was placed in a chromatographic chamber with a solvent (the mobile phase, a mixture of petroleum and diethyl ether in the ratio of $4: 1$ ). To saturate the chamber with the vapor of the solvent, its side walls and the bottom are covered with filter paper. Upon reaching the finish mark, the chromatograms are transferred to the exhaust hood at the temperature of $110^{\circ} \mathrm{C}$.

Persistent color spots appear on silica gel. The chromatograms are placed in a glass jar, densely closed with bits of crystalline iodine. The developing process time is 10-20 minutes. After evaporation of iodine, the extract is harvested into pre-weighed bottles, and after complete removal of the solvent (with vacuum), the weighing bottles are weighed. The calibration curve is built for each individual class and their number is determined in the tested sample.

\section{Results and discussion}

The value of different lipids fractions, as can be seen from Table, in patients with VBI did not change unidirectionally. The amount of polar lipids before treatment was $0.17 \pm 0.004 \mathrm{mmol} / \mathrm{l}$, and after the treatment it increased to $0.19 \mathrm{mmol} / \mathrm{l}$. The Student's coefficient was 2.9 at the variationstatistical data processing. In the correlation data analysis before and after the treatment there was a high degree of unidirectional changes, which is confirmed by the respective correlation coefficient -0.7 . Changes in the amount of cholesterol esters in the hair of patients compared to the polar lipids were less statistically reliably pronounced. Free fatty acids have undergone very slight changes, which are not statistically reliable.

Triacyglycerides have undergone already more significant changes. Before treatment, their amount in tissues was $0.39 \pm 0.07 \mathrm{mmol} / \mathrm{l}$. After the treatment, their content in these tissues was $0.32 \pm 0.01 \mathrm{mmol} / \mathrm{l}$. with Student's coefficient of 0.89 . Such a sufficiently significant growth is statistically reliable $(\mathrm{p}<0.05)$. In the correlation analysis, mostly unidirectional changes were detected in over a third of the studied cases. 
Table. Content of lipid fractions in the patients' hair

\begin{tabular}{|c|c|c|c|c|c|}
\hline \multicolumn{2}{|c|}{ Lipid fractions before and after treatment } & Amount & $\mathbf{p}$ & $\mathbf{t}$ & $\mathbf{r}$ \\
\hline \multirow{2}{*}{ Polar lipids } & Before treatment & $0.17 \pm 0.004$ & \multirow{2}{*}{$<0.05$} & \multirow[t]{2}{*}{2.9} & \multirow[t]{2}{*}{0.7} \\
\hline & After treatment & $0.19 \pm 0.005$ & & & \\
\hline \multirow[t]{2}{*}{ Cholesterol esters } & Before treatment & $0.42 \pm 0.007$ & \multirow[t]{2}{*}{$\geq 0.05$} & \multirow[t]{2}{*}{1.9} & \multirow[t]{2}{*}{0.87} \\
\hline & After treatment & $0.44 \pm 0.008$ & & & \\
\hline \multirow{2}{*}{ Free fatty acids } & Before treatment & $0.35 \pm 0.03$ & \multirow{2}{*}{$\geq 0.05$} & \multirow[t]{2}{*}{1.9} & \multirow[t]{2}{*}{0.4} \\
\hline & After treatment & $0.36 \pm 0.04$ & & & \\
\hline \multirow[t]{2}{*}{ Triacyglyceride } & Before treatment & $0.39 \pm 0.07$ & \multirow[t]{2}{*}{$<0.05$} & \multirow[t]{2}{*}{0.89} & \multirow[t]{2}{*}{0.3} \\
\hline & After treatment & $0.32 \pm 0.01$ & & & \\
\hline \multirow[t]{2}{*}{ Free cholesterol } & Before treatment & $0.42 \pm 0.009$ & \multirow[t]{2}{*}{$<0.05$} & \multirow[t]{2}{*}{2.4} & \multirow[t]{2}{*}{0.89} \\
\hline & After treatment & $0.39 \pm 0.008$ & & & \\
\hline
\end{tabular}

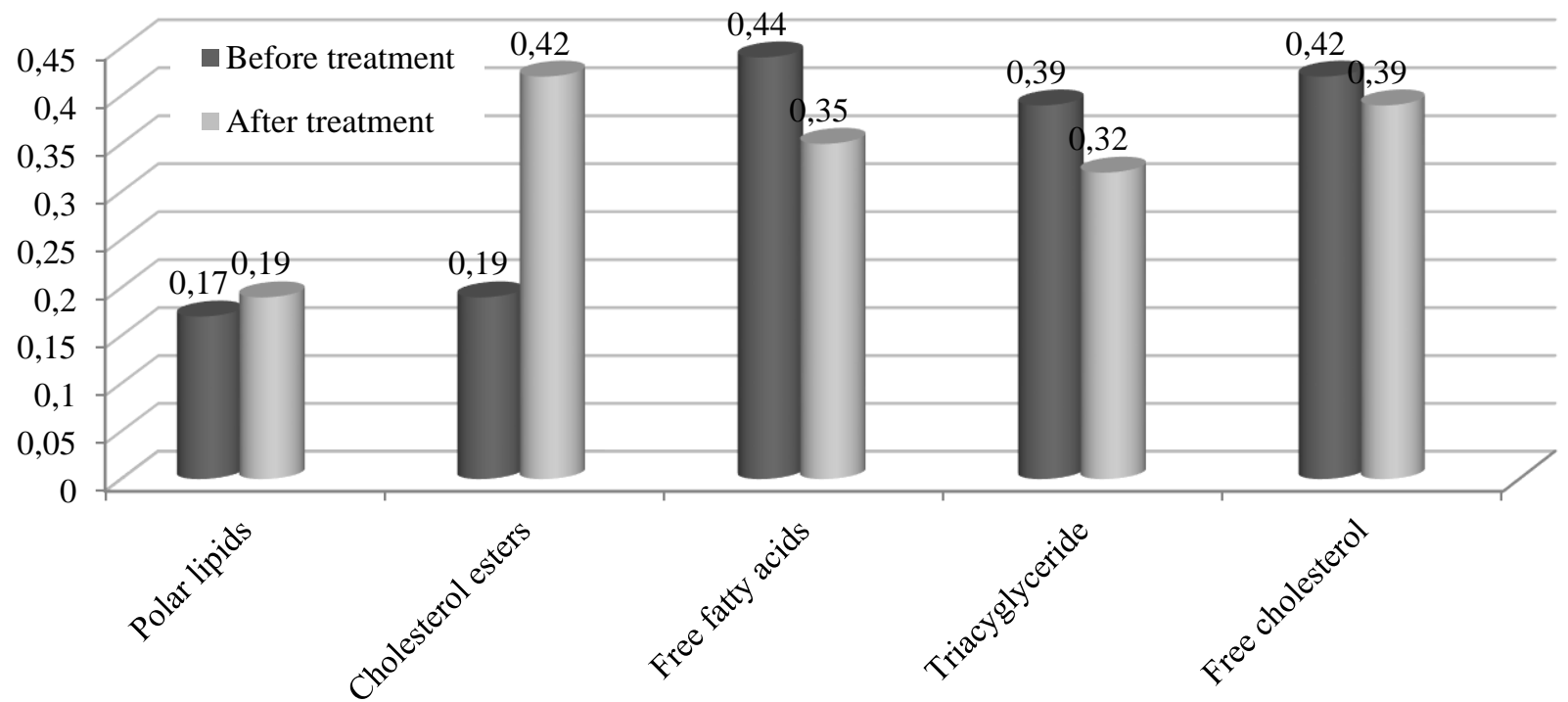

Fig. Lipids content changes before and after the treatment performed.

Free cholesterol before treatment was $0.42 \pm$ $0.009 \mathrm{mmol} / \mathrm{l}$. After treatment, its value dropped to $0.39 \pm 0.008$ $\mathrm{mmol} / \mathrm{l}$, which is statistically reliable. Free fatty acids at cerebral circulation disorder therapy (CCDT) have undergone very small, statistically unreliable changes. The control group served as a group of healthy adolescents numbering 20 persons ( 12 girls and 8 boys aged 15-18 years) in which the content of lipid fractions in hair was distributed as follows: polar lipids $-0.24 \mathrm{mmol} / \mathrm{l}$, cholesterol esters $-0.45 \mathrm{mmol} / \mathrm{l}$, free fatty acids $-0.37 \mathrm{mmol} / \mathrm{l}$, triacyglycerides $-0.31 \mathrm{mmol} / \mathrm{l}$, free cholesterol $-0.375 \mathrm{mmol} / \mathrm{l}$.

When applying physical therapy, we see some changes in most of the lipid fractions in the hair. As it can be seen from figure 1 , there was a statistically reliable increase in the polar lipids amount after treatment, and a statistically reliable decrease in free cholesterol and triacyglycerides. At the same time, the value of free cholesterol and triacyglycerides reached the normal level in the control group of the studied patients.

Such a result has its scientific explanation and practical significance. Considering that the polar lipids fraction is nonatherogenic, whereas free cholesterol and triacylglycerides contribute to atherogenesis [8], the increase in the polar lipids amount and the decrease in the amount of triacyglycerides and free cholesterol after treatment can be interpreted as a positive effect of the performed physical therapy on this vascular pathology regression.

In the objective and instrumental examination of adolescents after the performed treatment, a clear positive dynamics of pathological symptoms regression was observed. Namely: in most of the examined patients, periodic dizziness, headache, visual impairment, vertebral listhesis and smoothed lordosis disappeared, in some cases the symptoms became very slight. On the ultrasound scans of extracranial vessels after treatment, the signs of extravasal compression of the vertebral arteries were not observed in more than half of the patients, while in the rest they became significantly less pronounced.

\section{Prospects for further researches}

Conduct research into the effectiveness of physical therapy using theoretical and methodological and pedagogical analysis in a comprehensive study of aspects of correction of vertebral-basilar syndrome in students. 


\section{Conclusions}

1. The obtained data indicate a certain value of the tissue lipids content disorder in the pathogenesis of the vertebrobasilar insufficiency syndrome.
2. Correction of the cervical spine vertebral disorders by means of physical therapy leads to the elimination of extravascular compression signs and the restoration of lipid metabolism in tissues, which is accompanied by improvement of the clinical condition in patients and by the neurological deficiency regression.

\section{Література}

1. Григорова І.А., Тихонова Л.В., Некрасова Н.О. Клініко-неврологічні, рентгенологічні і гемодинамічні зміни у пацієнтів молодого віку з проявами веретебробазилярної судинної недостатності; Медицина сегодня и завтра. 2011; $101-107$.

2. Зозуля І.С., Несукай В.Г., Транзиторні ішемічні атаки у вертебрально-базилярній системі, зумовлені патологією шийного відділу хребта; Ліки України. 2013; 3: 4-9.

3. Калашніков В.И. Синдром позвоночной артерии: клинические варианты, классификация, принципы диагностики и лечения; Международный неврологический журнал. 2010; 1(31): 31-33.

4. Коваленко O.С., Клініко-діагностична характеристика, профілактика та лікування порушень кровообігу в вертебральнобазилярному басейні при патології шийного відділу хребта : Автореф. дис. докт. мед. наук. : спец. 14.00.13 “Нервові хвороби”. Київ, 2007. 36 с.

5. Лабінський А.Й. Ефективність фізичної терапії хвороби Паркінсона / Лабінський А.Й., Лабінська Г.Б. // Збірник статей учасників двадцять шостої всеукраїнської практично-пізнавальної конференції, частина I «Наукова думка сучасності і маібутного» //Дніпро // 2019//С.15-18.

6. Лабінський А.Й. Комбіноване застосування нутриціологічної корекції, гірудо-та мануальної терапії в пацієнтів 3 немоторними виявами хвороби Паркінсона / I. М. Карабань, А. Й. Лабінський // Український неврологічний журнал-2016р.Випуск 4- С. 55-58.

7. Некрасова Н.О. Діагностика вертебро-базилярної недостатності у осіб молодого віку: принципи та досвід клінікоінструментальної верифікації спондилогенного походження; вісник ВДНЗУ «Українска медична стоматологічна академія». Вісник Українскої медичної стоматолгічної академії “Актуальні проблеми сучасної медицини”. 2018; 18(2, 62): 84-89.

8. Нефедов А.Ю. Патогенез и диагностика спондилогенной недостаточности кровообращения в вертебральнобазилярной системе. Новые подходы к лечению. Автореф. дисс. д-ра мед. наук.: спец. 14.00.13 “Нервные болезни”. Москва, 2005. $42 \mathrm{c}$.

9. Новосельцев С.В. Спондилогенно-краниальная недостаточность мозгового кровообращения в вертебральнобазилярном бассейне и ее коррекция. Автореф. дис. канд. мед. наук.: спец. 14.00.13 “Нервные болезни”. СПб.: СПбГМУ ім. І.П. Павлова, 2004. 36 с.

10. Петухова Н.А., Камчатнов П.Р. Результаты коррекции дислипопротеидемии у больных синдромом вертебробазилярной недостаточности. Неврологический вестник. 2001; 33(3-4): 13-17.

11. Ткачук В.М., Стапай П.В. Дослідження воску журопоту і ліпідів вовни овець: методичні рекомендації. Львів, 2011. $24 \mathrm{c}$

\section{References}

1. Hryhorova IA, Tykhonova LV, Nekrasova NO. Kliniko-nevrolohichni, renthenolohichni i hemodynamichni zminy u patsiyentiv molodoho viku z proyavamy veretebrobazylyarnoyi sudynnoyi nedostatnosti. Meditsina sehodnya i zavtra. $2011 ; 101-107$.

2. Zozulya IS, Nesukay VH. Tranzytorni ishemichni ataky u vertebro-bazylyarniy systemi, zumovleni patolohiyeyu shyynoho viddilu khrebta. Liky Ukrayiny. 2013; 3: 4-9.

3. Kalashnikov VI. Sindrom pozvonochnoy arterii: klinicheskiye varianty, klassifikatsiya, printsipydiagnostiki i lecheniya. Mezhdunarodnyi nevrologicheskiy zhurnal. 2010; 1(31): 31-33.

4. Kovalenko OYe. Kliniko-diahnostychna kharakterystyka, profilaktyka ta likuvannya porushen krovoobihu v vertebralnobazylyarnomu baseyni pry patolohiyi shyynoho viddilu khrebta: Avtoref. dys. ... dokt. med. nauk. : spets. 14.00.13 "Nervnyie bolezni". Kyiv, 2007. $36 \mathrm{~s}$.

5. Labinskyi A.I. Efektyvnist fizychnoi terapii khvoroby Parkinsona/ Labinskyi A.I., Labinska H.B. // Zbirnyk statei uchasnykiv dvadtsiat shostoi vseukrainskoi praktychno-piznavalnoi konferentsii, chastyna I «Naukova dumka suchasnosti i maibutnoho» //Dnipro // 2019//S.15-18.

6. Labinskyi A.I. Kombinovane zastosuvannia nutrytsiolohichnoi korektsii, hirudo-ta manualnoi terapii $\mathrm{v}$ patsiientiv $\mathrm{z}$ nemotornymy vyiavamy khvoroby Parkinsona / I. M. Karaban, A. Y. Labinskyi // Ukrainskyi nevrolohichnyi zhurnal-2016r.- Vypusk 4- S. 55-58.

7. Nekrasova NO. Diahnostyka vertebro-bazylyarnoyi nedostatnosti u osib molodoho viku: pryntsypy ta dosvid klinikoinstrumentalnoyi veryfikatsiyiyiyi spondylohennoho pokhodzhennya, visnyk VDNZU «Ukrayinska medychna stomatolohichna akademiya». Visnyk Ukrayinskoyi medychnoyi stomatolohichnoyi akademiyi “Aktualni problemy suchasnoyi medytsyny”. 2018; 18(2, 62): 84-89.

8. Nefiodov AYu. Patogenez i diagnostika spondilogennoy nedostatochnosti krovoobrashcheniya v vertebralno-bazilyarnoy sisteme. Novyie podkhody k lecheniyu. Avtoref. diss. ... d-ra med. nauk. : spets. 14.00.13 "Nervnyie bolezni”. Moskva, 2005.42 s. 
9. Novoseltsev SV. Spondilogenno-kranialnaya nedostatochnost mozgovogo krovoobrashcheniya v vertebralnobazilyarnom basseyne i yeye korrektsiya. Avtoref. diss. ... kand. med. nauk. : spets. 14.00.13 "Nervnyie bolezni". SPb.: SPbGMU im. I.P. Pavlova, 2004. 36 s.

10. Petukhova NA., Kamchatnov PR. Rezultaty korrektsii dislipoproteidemii u bolnykh sindromom vertebrobazilyarnoy nedostatochnosti. Nevrologicheskiy vestnik. 2001; 33(3-4): 13-17.

11. Tkachuk VM, Stapay PV. Doslidzhennya vosku zhyropotu i lipidiv vovny ovets: metodychni rekomendatsiyi. Lviv, 2011. $24 \mathrm{~s}$.

Дата надходження рукопису до редакції: 16.01 .2020 р.

The purpose of the work was to study the effect of physical therapy on the course of vertebrobasilar syndrome in adolescents.

Materials and methods. In the complex of physical therapy, methods of therapeutic exercises, treatment, massage, tractionmanual therapy, and electrophysiotherapeutic procedures were used. The tissues lipid spectrum study was carried out according to the modified Folch method and permits to obtain the largest amount of lipids from the tissues.

Results. The therapeutic effect of physical therapy was manifested not only in the normalization of lipid metabolism, but in reducing the severity of the main clinical disease manifestations, which makes expedient the use of this therapy.

Conclusions. Correction of the cervical spine vertebral disorders by means of physical therapy leads to the elimination of extravascular compression signs and the restoration of lipid metabolism.

Key words: physical rehabilitation therapy, vertebrobasilar insufficiency syndrome, tissue lipid balance.

Метою роботи було вивчення впливу фізичної терапії на перебіг вертебробазилярного синдрому у підлітків.

Матеріали та методи. У комплексі фізичної терапії були використані методи лікувальної гімнастики, лікувального масажу, тракційно-мануальної терапії, електрофізіотерапевтичних процедури. Дослідження ліпідного спектра тканин проводилося за модифікованим методом Фолча і дозволяє отримувати найбільшу кількість ліпідів 3 тканин.

Результати. Терапевтичний ефект фізичної терапії проявлявся не тільки в нормалізації ліпідного обміну, але і в зниженні вираженості основних клінічних проявів захворювання, що робить доцільним застосування даної терапії.

Висновки. Корекція порушень хребта шийного відділу хребта за допомогою фізичної терапії призводить до усунення ознак Екстраваскулярний здавлювання в вертебробазилярном басейні і відновленню ліпідного обміну.

Ключові слова: фізична терапія, синдром вертебробазилярної недостатності, тканинної ліпідний баланс.

Целью работы было изучение влияния физической терапии на течение вертебробазилярного синдрома у подростков.

Материалы и методы. В комплексе физической терапии были использованы методы лечебной гимнастики, лечебного массажа, тракционно-мануальной терапии, электрофизиотерапевтические процедуры. Исследование липидного спектра тканей проводилось по модифицированному методу Фолча и позволяет получать наибольшее количество липидов из тканей.

Результаты. Терапевтический эффект физической терапии проявлялся не только в нормализации липидного обмена, но и в снижении выраженности основных клинических проявлений заболевания, что делает целесообразным применение данной терапии.

Выводы. Коррекция нарушений позвоночника шейного отдела позвоночника с помощью физической терапии приводит к устранению признаков экстраваскулярного сдавливания в вертебробазилярном басейне и восстановлению липидного обмена.

Ключевые слова: физическая терапия, синдром вертебробазилярной недостаточности, тканевой липидный баланс.

Конфлікт інтересів: відсутній.

Conflicts of interest: authors have no conflicts of interest to declare.

\section{Відомості про авторів}

Лабінський Андрій Йосифович - кандидат медичних наук, доцент, завідувач кафедри реабілітації та здоров’я людини Львівського національного університету ветеринарної медицини та біотехнологій імені С. Гжицького; м. Львів, вул. Пекарська 50 .

+380 (96) 469-70-10, lajboxnet@gmail.com.

Лабінська Галина Богданівна - лікар-педіатр, фізіотерапевт, асистент кафедри фізичного виховання, спорту і здоров'я Львівського національного університету ветеринарної медицини та біотехнологій імені С. Гжицького; м. Львів, вул. Пекарська 50 .

+380 (98) 778-20-87. 